\title{
THE EFFECT OF TEMPERATURE ON NEURAL TASTE RESPONSE OF CATS
}

\author{
Satoru Yamashita, Kazuhiro Yamada \\ AND Masayasu SATo* \\ Department of Physiology, Kumamoto University \\ Medical School, Kumamoto, Japan
}

In the preceding paper NAGAKI, YAMASHITA and SATO ${ }^{7)}$ have shown that the magnitude of response of the chorda tympani nerve of cats to taste stimuli was, in most cases, greatest when the temperature of taste solutions was at about $30^{\circ} \mathrm{C}$ or at the temperature of the tongue. In this study, however, the temperature of the tongue was not controlled accurately, but only the temperature of solutions was changed. Consequently, both thermal and taste responses were included in the chorda tympani response, and the magnitude of taste response at various temperatures had to be estimated by subtracting the thermal response from the whole chorda tympani response to a taste solution at any temperature.

In the present study the tongue had been adapted to a certain temperature before taste stimulations were performed in order to eliminate the thermal response and to measure only the magnitude of taste response. This method of preadapting the tongue to a temperature similar to that of stimulating solution, adopted previously by АВBOT ${ }^{1)}$ on rats, has enabled us to work out the relationship between the taste response of the chorda tympani and temperature more accurately than did the previous experiment. The results of the present experiment confirm those of the previous study, showing that the greatest taste response is obtained at about $30^{\circ} \mathrm{C}$ for four kinds of taste solutions.

\section{METHODS}

Twelve adult cats were used in this experiment. The experimental methods were almost the same as those described in the preceding paper ${ }^{7}$ except for that of the stimulation of the tongue. Temperature of the surface of the tongue, measured with a thermistor, ranged from $29.2^{\circ}$ to $33.4^{\circ} \mathrm{C}$ (mean of twelve cats $30.8^{\circ} \mathrm{C}$ ).

The magnitude of the integrated response immediately and $10 \mathrm{sec}$ after the stimulation was measured and taken as representing the magnitude of initial and steady

Received for publication July 16, 1964

*山下 智, 山田和廣, 佐藤昌康 
responses, respectively.

Method of stimulation. First, Ringer's solution of a certain temperature was passed into a flow chamber, in which the tongue had been placed. One minute after the onset of the flow of Ringer's solution, during which the thermal response of the chorda tympani nearly subsided and temperature of the tongue attained almost a steady level (FIG. 1), the first stimulus was applied to the tongue through a flow chamber. The stimulation lasted for $15 \mathrm{sec}$ and this was followed by a flow of Ringer's solution. Thirty seconds after the end of the first stimulus the next stimulus was applied for $15 \mathrm{sec}$, followed by a flow of Ringer's solution for $30 \mathrm{sec}$ and finally the third stimulus was given to the tongue. In this way three successive stimulations were made, each being interposed by a flow of Ringer's solution for $30 \mathrm{sec}$. Each stimulus had the same temperature as that of the preadapting Ringer's solution, so that the thermal response could be avoided. When the three successive stimuli were identical, the successive chorda tympani responses showed almost equal magnitude, as shown in Fig. 1. This ensures that the preceding stimulus does not affect the subsequent response.

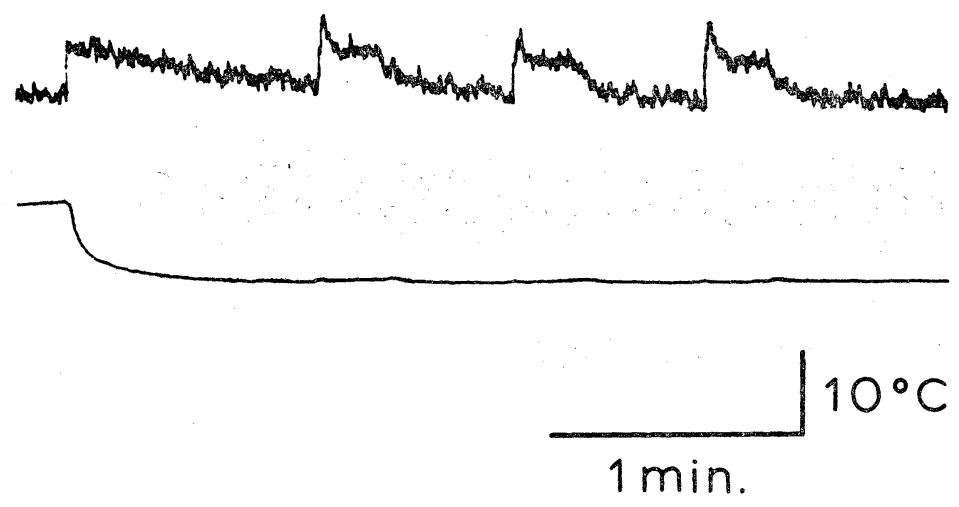

FIG. 1. Integrated response of the chorda tympani of a cat to three successive stimulations of the tongne by $0.5 \mathrm{M} \mathrm{NaCl}$ of $20^{\circ} \mathrm{C}$, preceded by a flow of Ringer's solution at the same temperature (upper trace), and temperature change of the surface of the tongue (lower trace).

Experiments on the lingual nerve. Three cats out of the 12, used in this experiment, were employed for investigating the response of the lingual nerve to thermal stimulation of the tongue. For the stimuli Ringer's solution of varying temperatures was applied through a flow chamber to the tongue for more than $1 \mathrm{~min}$.

Solutions. As test stimuli $0.25,0.5$ and $1 \mathrm{M} \mathrm{NaCl}, 0.5 \mathrm{M} \mathrm{KCl}, 0.005 \mathrm{M}$ quinine hydrochloride and $0.005 \mathrm{M} \mathrm{HCl}$ were employed, $\mathrm{NaCl}$ and $\mathrm{KCl}$ being dissolved in deionized water and quinine and $\mathrm{HCl}$ in Ringer's solution ( $\mathrm{NaCl} 154 \mathrm{mM}, \mathrm{KCl} 5.6 \mathrm{mM}$, $\left.\mathrm{CaCl}_{2} 2.16 \mathrm{mM}\right)$.

\section{RESULTS}

Response to $\mathrm{NaCl}$. Three experiments using $0.25,0.5$ and $1 \mathrm{M} \mathrm{NaCl}$ as test stimuli were carried out. The results are summarized in FIG. 2, in which each point indicates average of three experimental results. FIG. 2 indicates 

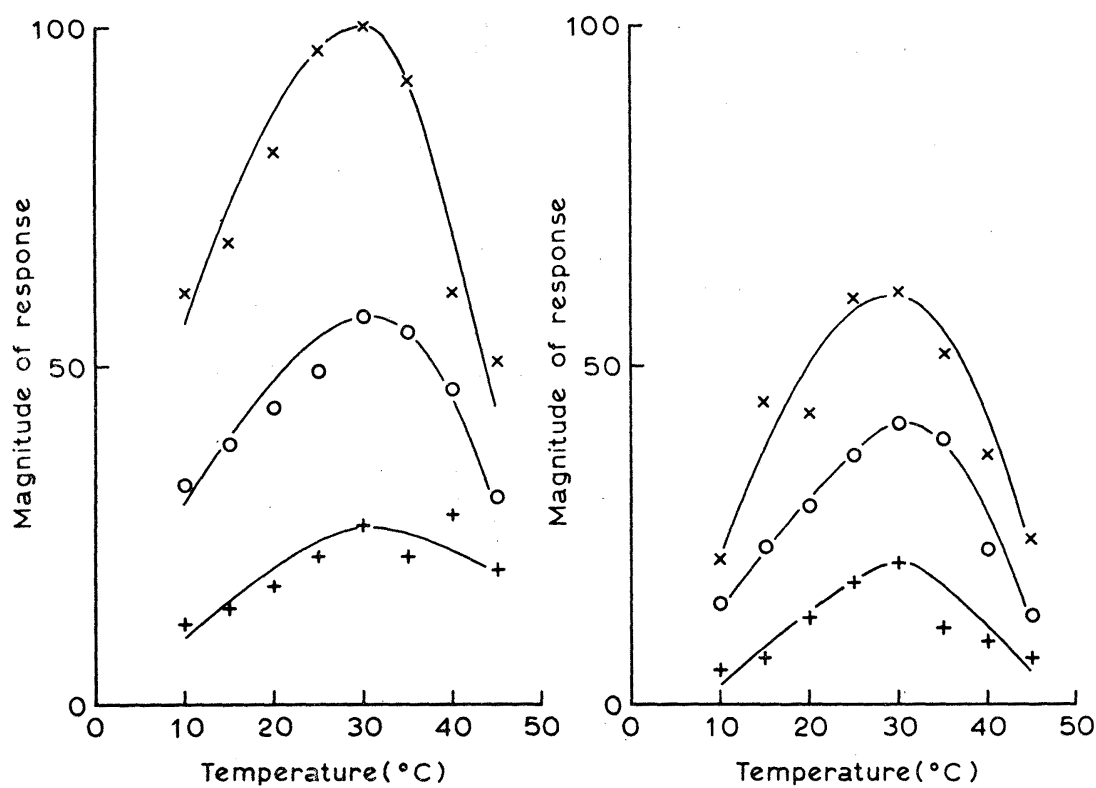

Fig. 2. Relationship between the magnitude of response to $1 \mathrm{M}(x)$, $0.5 \mathrm{M}(\bigcirc)$ and $0.25 \mathrm{M}(+) \mathrm{NaCl}$ and temperature. The magnitude of the initial response is shown in the left and that of the steady response (10 sec after the stimulation) in the right. Each point represents the average value of three experiments, expressed relative to the magnitude of response to $1 \mathrm{M} \mathrm{NaCl}$ at $30^{\circ} \mathrm{C}$.

that the magnitude of response immediately and $10 \mathrm{sec}$ after the stimulation shows a maximum value at $30^{\circ} \mathrm{C}$ for all concentrations except the initial value for $0.25 \mathrm{M}$. The response to $0.25 \mathrm{M} \mathrm{NaCl}$ in FIG. 2 is greatest at $40^{\circ} \mathrm{C}$. However, this does not seem to be significant, because in one experiment the greatest response magnitude was obtained at $30^{\circ} \mathrm{C}$, and in another experiment at both $30^{\circ}$ and $40^{\circ} \mathrm{C}$ while in the remaining experiment the value at $40^{\circ} \mathrm{C}$ was exceptionally greater than those at other temperatures. From this one may probably be safe to assume that the magnitude of response to $0.25 \mathrm{M} \mathrm{NaCl}$ shows a maximum value at $30^{\circ} \mathrm{C}$.

Response to $\mathrm{HCl}, \mathrm{KCl}$ and quinine. Two experiments were carried out using $5 \mathrm{mM} \mathrm{HCl}, 5 \mathrm{mM}$ quinine and $0.5 \mathrm{M} \mathrm{NaCl}$ as test stimuli and four experiments using $5 \mathrm{mM} \mathrm{HCl}, 5 \mathrm{mM}$ quinine and $0.5 \mathrm{M} \mathrm{KCl}$. An example of the latter experiments is shown in FIG. 3, and all the results of 6 experiments are summarized in FIG. 4, in which the magnitude of responses to $\mathrm{NaCl}, \mathrm{KCl}$ and quinine relative to that for $\mathrm{HCl}$ at $30^{\circ} \mathrm{C}$ is shown as function of temperature. FIG. 4 indicates that $0.5 \mathrm{M} \mathrm{NaCl}, 5 \mathrm{mM} \mathrm{HCl}$ and $5 \mathrm{mM}$ quinine produce a maximum response at $30^{\circ} \mathrm{C}$ while the greatest response for $\mathrm{KCl}$ lies at $35^{\circ} \mathrm{C}$. The magnitude of response $10 \mathrm{sec}$ after the stimulation shows a maximum at 

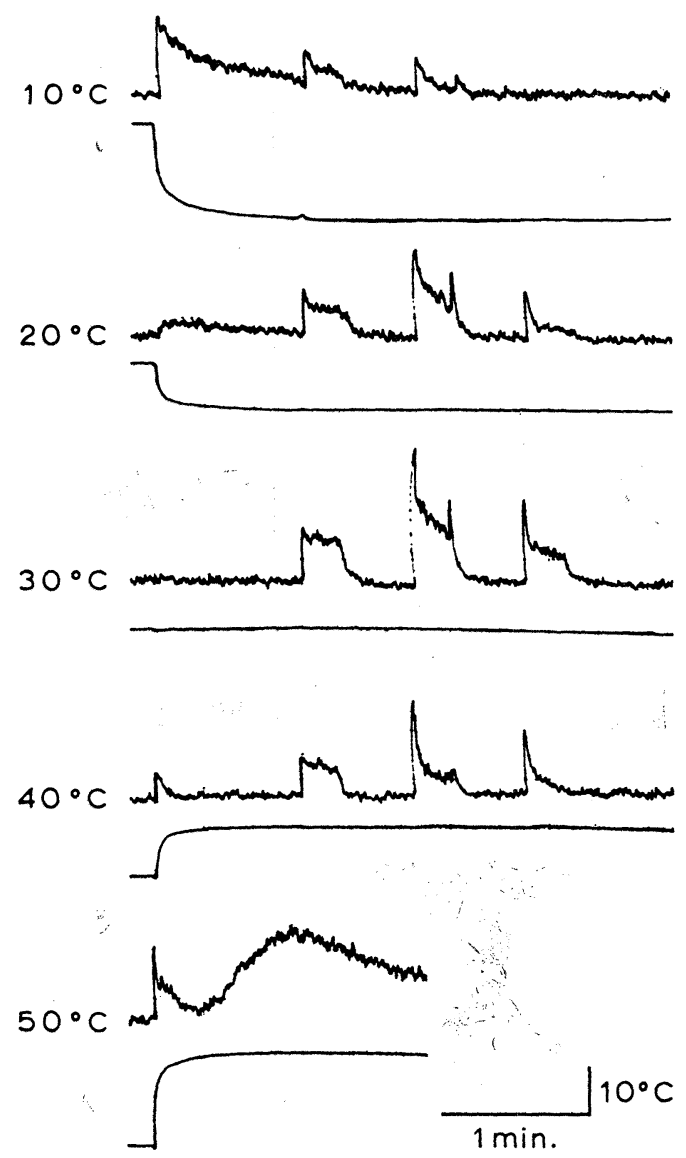

FIG. 3. Integrated response of the chorda tympani to three successive stimulations of the tongue by $0.5 \mathrm{M} \mathrm{KCl}, 5 \mathrm{mM}$ quinine and $5 \mathrm{mM} \mathrm{HCl}$, preceded by a flow of Ringer's solution at varying temperatures (upper trace), and temperature change in the tongue (lower trace). In the experiment at $50^{\circ} \mathrm{C}$ only Ringer's solution was applied to the tongue.

$30^{\circ} \mathrm{C}$ not only for $\mathrm{NaCl}, \mathrm{HCl}$ and quinine but also for $\mathrm{KCl}$ (FIG. 4, right). The magnitude of the initial response to $\mathrm{KCl}$ was greatest at $30^{\circ} \mathrm{C}$ in one experiment, at $40^{\circ} \mathrm{C}$ in another and at $35^{\circ} \mathrm{C}$ in the remaining two experiments. Therefore it is rather likely that the magnitude of initial response to $\mathrm{KCl}$ shows a higher optimal temperature than that to other kinds of stimuli.

The relative magnitude of response to $0.5 \mathrm{M} \mathrm{NaCl}, 0.5 \mathrm{M} \mathrm{KCl}, 5 \mathrm{mM} \mathrm{HCl}$ and $5 \mathrm{mM}$ quinine, calculated from the initial response magnitude, is $\mathrm{NaCl}$ : $\mathrm{KCl}: \mathrm{HCl}:$ quinine $=0.36: 1.00: 1.72: 1.50$ at $30^{\circ} \mathrm{C}$, but it becomes $0.28: 1.00$ : $1.17: 1.15$ at $10^{\circ} \mathrm{C}$ and $0.25: 1.00: 0.75: 0.48$ at $45^{\circ} \mathrm{C}$, while the response ratio for the steady response magnitude is $0.51: 1.00: 2.14: 1.32$ at $30^{\circ} \mathrm{C}, 0.13: 1.00$ : 1.06: 0.74 at $10^{\circ} \mathrm{C}$ and $0.77: 1.00: 0.91: 0.40$ at $45^{\circ} \mathrm{C}$. Although these ratios 

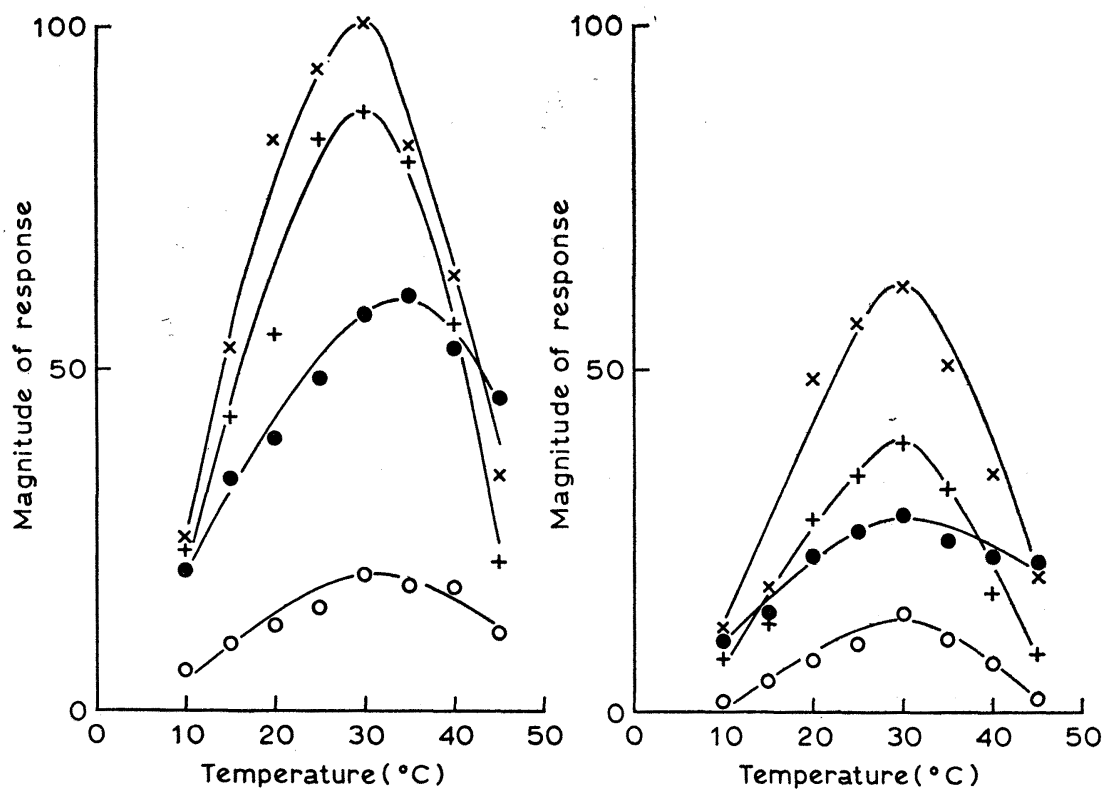

FIG. 4. Relationship between the magnitude of response to $0.5 \mathrm{M} \mathrm{NaCl}$ $(\bigcirc), 0.5 \mathrm{M} \mathrm{KCl}(\bigcirc), 5 \mathrm{mM}$ quinine $(+)$ and $5 \mathrm{mM} \mathrm{HCl}(\times)$ and temperature. The magnitude of the initial response is shown in the left and that obtained $10 \mathrm{sec}$ after the stimulation in the right. Each point represents the average value of two experiments for $\mathrm{NaCl}$, four experiments for $\mathrm{KCl}$ and six experiments for quinine and $\mathrm{HCl}$, and is expressed relative to the magnitude of response to $\mathrm{HCl}$ at $30^{\circ} \mathrm{C}$.

are very approximate, it may be concluded that the relative magnitude of response to acid and quinine decreases markedly at very cold or warm temperatures.

Temperature coefficients of taste response. From the results of 9 experiments the temperature coefficient $\left(Q_{10}\right)$ for the magnitude of response to four

TABLE 1

Temperature coefficients $\left(Q_{10}\right)$ for the chorda tympani response to $\mathrm{NaCl}, \mathrm{KCl}$, $\mathrm{HCl}$ and quinine at respective temperature range.

\begin{tabular}{l|c|l|l|l}
\hline $\begin{array}{c}\text { Stimulating } \\
\text { solutions }\end{array}$ & $\begin{array}{c}\text { Number of } \\
\text { experiments }\end{array}$ & $10^{\circ}-20^{\circ} \mathrm{C}$ & $15^{\circ}-25^{\circ} \mathrm{C}$ & \multicolumn{1}{|c}{$35^{\circ}-45^{\circ} \mathrm{C}$} \\
\hline $0.5 \mathrm{M} \mathrm{NaCl}$ & 5 & 1.54 & 1.38 & -1.70 \\
$0.5 \mathrm{M} \mathrm{KCl}$ & 4 & $1.92(2.16)$ & $1.43(1.83)$ & $-1.31(-1.14)$ \\
$5 \mathrm{mM} \mathrm{HCl}$ & 6 & $3.46(4.33)$ & $1.76(1.99)$ & $-2.38(-2.50)$ \\
$5 \mathrm{mM} \mathrm{Quinine}$ & 6 & $2.34(3.50)$ & $1.93(2.53)$ & $-3.60(-3.64)$ \\
\hline
\end{tabular}

Numerals in the parentheses indicate the $Q_{10}$ for the steady response magnitude and those outside that for the initial response magnitude. 
kinds of taste stimuli is calculated and is shown in TABLE 1 . As can be seen in this table, $\mathrm{Q}_{10}$ for the response to $\mathrm{NaCl}$ and $\mathrm{KCl}$ is about 2 between $10^{\circ}$ and $30^{\circ} \mathrm{C}$ and less than -2 between $35^{\circ}$ and $45^{\circ} \mathrm{C}$, while $\mathrm{Q}_{10}$ for the quinine and $\mathrm{HCl}$ response is much greater than the former. Such distinct differences in the $\mathrm{Q}_{10}$ values between the responses to salts and those to acid and quinine suggest that the reaction between taste receptors and stimulating substances are not the same in these two groups of stimulations, and a relatively small $Q_{10}$ value for the salt response indicates that the reaction is physical or physicochemical rather than enzymatic.

Response of the chorda tympani and the lingual nerve to temperature change of the tongue. At the onset of a flow of Ringer's solution of varying temperatures over the tongue thermal responses appeared in the chorda tympani FIGS. 1 and 3). The response attained a maximum magnitude immediately after the onset of the flow and ceased approximately during the next minute. The magnitude of response, measured immediately after the flow, was increased as the temperature was lowered or raised from $30^{\circ} \mathrm{C}$, where little response was seen; this confirmed the results by NAGAKI et al. ${ }^{(7)}$. In addition, when the temperature was raised to as high as $50^{\circ} \mathrm{C}$, a massive and persistent discharge appeared following the initial thermal response (FIG. 3, bottom record). This response is different in its time of occurrence and pattern from the thermal response and may be considered as a pain discharge.

The lingual nerve response to thermal change of the tongue differed from the chorda tympani response, as shown by NAGAKI et al. ${ }^{7}$. An example of the integrated response of the lingual nerve is shown in FIG. 5. As seen in this figures, there is a transient and big response to the lowering of temperature, but on raising the temperature the level of the integrator output was lowered and a further rise in temperature resulted in a delayed but massive

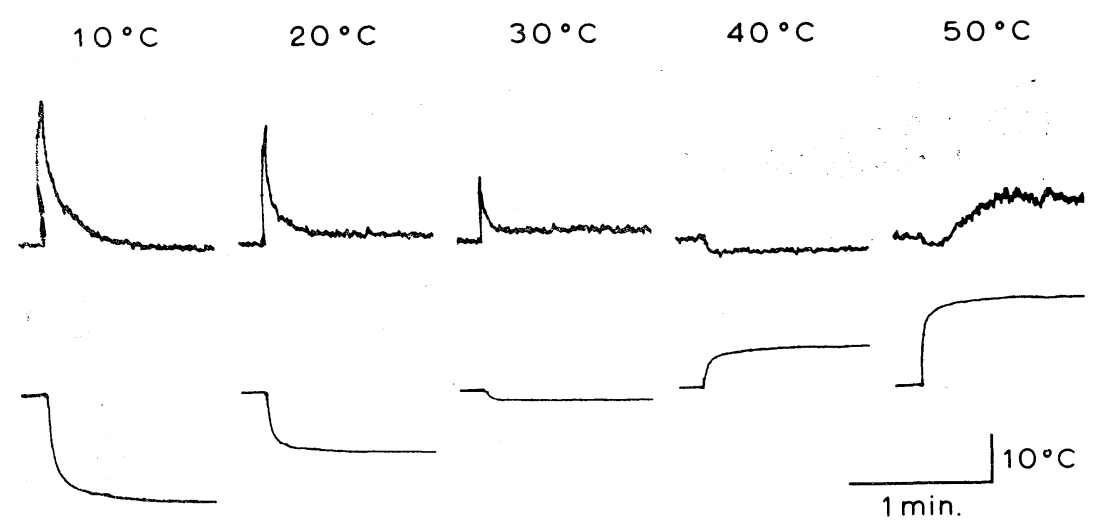

FIG. 5. Integrated response of the lingual nerve to thermal stimulation of the tongue (upper trace) and change in temperature of the tongue (lower trace). 


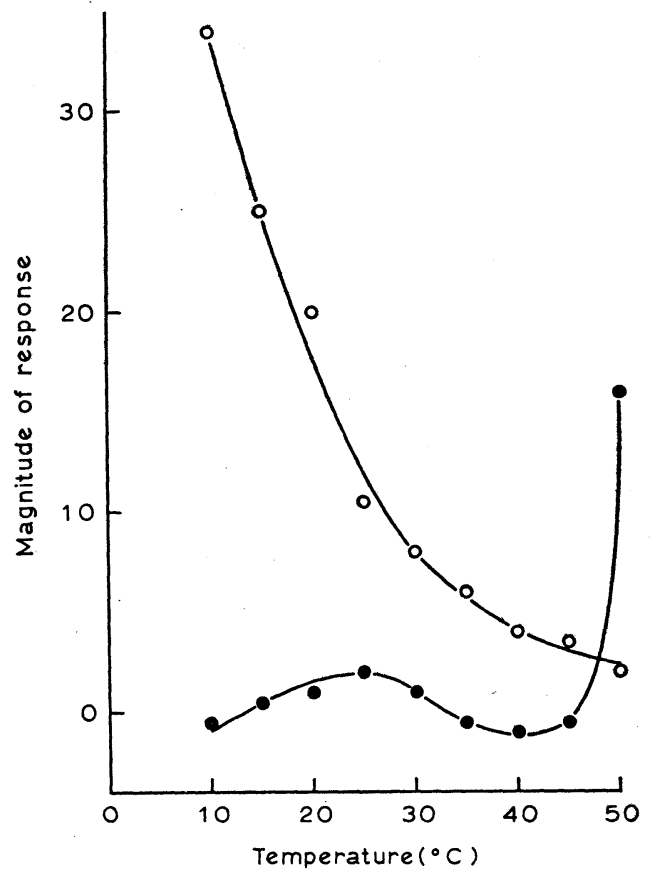

FIG. 6. Relationship between the magnitude of the lingual nerve response to thermal change of the tongue and temperature. $\bigcirc$; the magnitude of response immediately after stimulation, and 0 ; the magnitude of response $1 \mathrm{~min}$ after stimulation.

discharge (record at $50^{\circ} \mathrm{C}$ in FIG. 5). The delayed discharge at $50^{\circ} \mathrm{C}$ is the same in its pattern as that in the chorda tympani, and is also considered as a pain discharge. The relationship between the magnitude of thermal response immediately and $1 \mathrm{~min}$ after the stimulation and the temperature is shown in FIG. 6. The initial response tends to become smaller in magnitude as the temperature gets higher, while the magnitude of the steady response shows a maximum at $25^{\circ} \mathrm{C}$.

\section{DISCUSSION}

NAGAKI et $a l .{ }^{7)}$ have shown that the greatest taste response of the chorda tympani of cats to stimulation of the tongue by $\mathrm{NaCl}$, quinine and $\mathrm{HCl}$ is obtained when the temperature of taste solutions is at about $30^{\circ} \mathrm{C}$ or at the temperature of the tongue. In their experiment taste receptors were stimulated by solutions of varying temperatures, and consequently the magnitude of taste response was estimated by subtracting the thermal response from the whole response of the chorda tympani at each temperature. However, the present experiment, in which the thermal response was eliminated by 
preadapting the tongue to the temperature for stimulation, yielded the results similar to those by NAGAKI et al. ${ }^{7}$. Although in the paper by NAGAKI et $a ._{.7}{ }^{7}$ the optimal temperature for $\mathrm{NaCl}$ has been shown to vary as the concentration changes, this has not been confirmed in the present experiment.

Temperature characteristic of the taste response such as showing an optimal temperature at $30^{\circ}-35^{\circ} \mathrm{C}$ appears to be a common attribute of all mammals, since similar observations to those on cats have been shown on rats by SATO and YAMASHITA ${ }^{8)}$. However, taste receptors of insects and amphibians behave differently from those of mammals with respect to temperature change. The former is not influenced significantly by changes in temperature at which stimulations are carried out ${ }^{2,5)}$, and the latter shows the optimal temperature close to the environmental temperature where animals live but differing to some extent according to the quality of taste stimuli ${ }^{6,9)}$.

The temperature coefficient for the magnitude of response to various kinds of stimuli has been calculated. The $\mathrm{Q}_{10}$ values for $\mathrm{NaCl}$ and $\mathrm{KCl}$ are small compared with those for $\mathrm{HCl}$ and quinine; such small $\mathrm{Q}_{10}$ values for the former as shown in the table probably indicate that the reaction between these ions and taste receptors is of physical or physicochemical nature and the marked difference between the $\mathrm{Q}_{10}$ values for salts and those for $\mathrm{HCl}$ and quinine suggests that the reaction involved in these two cases of stimulation is of different one. Similar results were obtained on frogs by YAMASHITA ${ }^{9)}$ and on rats by SATO and YAMASHITA ${ }^{8)}$.

In the above discussion it has been assumed that the neural response reflects the magnitude and the time course of the receptor process in taste cells which ultimately leads to repetitive initiation of impulses at the nerve terminal and that temperature change affects the receptor process exclusively. However, it may be possible that temperature change itself affects the electrical properties, such as the threshold, recovery period and accommodation, of nerve terminals innervating taste cells, thereby modifying the chorda tympani nerve response to taste stimulation. But it is difficult to assess how much this contributes to the results obtained in the present experiment. On the contrary, since there is evidence that almost all taste units in the chorda tympani of cats respond to temperature change as wel1 ${ }^{7}$, indicating that temperature change can modify properties of taste cells, the present authors are inclined to consider that changes in the neural response reflect, to a great extent, variations in the receptor process.

In the results behaviours of the chorda tympani nerve and of the glossopharyngeal nerve to thermal stimuli of the tongue were described. The chorda tympani shows an increasing magnitude of response with increasing difference in temperature between the flowing solutions and the tongue, while the lingual nerve indicates a decreasing magnitude of response with increasing temperature of solutions. Such results are in good agreement with those 
by NAGAKI et $a l .^{7}$. When the magnitude of response 1 min after the stimulation is measured, the lingual nerve response shows a maximum at $25^{\circ} \mathrm{C}$. This is consistent with the finding by HENSEL and ZOTTERMAN ${ }^{4}$ on single cold fibres in cats; they showed that discharge frequency in single cold fibres increases with temperature rise between $15^{\circ} \mathrm{C}$ and $25^{\circ} \mathrm{C}$, decreases to zero from $25^{\circ} \mathrm{C}$ to $35^{\circ} \mathrm{C}$ and rises further from about $47^{\circ} \mathrm{C}$. The discharge at about $50^{\circ} \mathrm{C}$ was called the paradoxical discharge by these authors. But the discharge observed in the lingual nerve at $50^{\circ} \mathrm{C}$ in the present experiment may not be the same as the paradoxical discharge, although the former includes the latter. The discharge in the lingual nerve at $50^{\circ} \mathrm{C}$ appears to result mostly from pain fibres, since i) the discharge pattern at $50^{\circ} \mathrm{C}$ is quite different from that at the temperature below $40^{\circ} \mathrm{C}$, ii) similar discharges were observed in the chorda tympani and iii) recordings of impulses in the present experiment were made from the whole nerve. The magnitude of steady thermal discharge in the chorda tympani declined as the temperature was raised up to $45^{\circ} \mathrm{C}$. This is probably because the nerve contains both cold and warm fibres $^{7)}$, the latter of which, according to the experimental results by DoDT and ZOTTERMAN ${ }^{3}$, should show a maximum frequency of impulses at steady temperature of about $40^{\circ} \mathrm{C}$.

\section{SUMMARY}

1. The effect of temperature change on the chorda tympani response of the cat has been investigated, by carrying out the stimulation of the tongue by $\mathrm{NaCl}, \mathrm{KCl}, \mathrm{HCl}$ and quinine at varying temperatures.

2. The greatest response magnitude was obtained at $30^{\circ} \mathrm{C}$ for $\mathrm{NaCl}, \mathrm{HCl}$ and quinine, while the response to $\mathrm{KCl}$ showed a maximum magnitude at $35^{\circ} \mathrm{C}$.

3. The $\mathrm{Q}_{10}$ values for $\mathrm{NaCl}$ and $\mathrm{KCl}$ stimulation were small compared with those for $\mathrm{HCl}$ and quinine. A possible significance of this result for the mechanism in receptor-substance reaction was discussed.

4. The thermal responses in both the chorda tympani and the lingual nerve to temperature change of the tongue were described.

\section{REFERENCES}

1) Аввотт, P.S. The effect of temperature on taste in the white rat. Providence, R. I., Brown Univ., 1953.

2) Dethier, V.G. And Arab, Y.M. Effect of temperature on the contact chemoreceptors of the blowfly. J. insect physiol., 2: 153-161, 1958.

3) Dodt, E. And Zotterman, Y. The mode of action of warm receptors. Acta physiol. scand., 26, 345-357, 1952.

4) Hensel, H. And Zotterman, Y. Quantitative Beziehungen zwischen der Entladung einzelner Kältefasern und der Temperature. Acta physiol. scand., 23 : 291319, 1951. 
5) Hodgson, E.S. Temperature sensitivity of primary chemoreceptors of insects. Anat. Rec., $125:$ 560-561, 1956.

6) Kimura, K. Effects of temperature on the response of chemoreceptors in frog tongue. Kumamoto Med. J., 15: 73-82, 1962.

7) NAgaki, J., Yamashita, S. And Sato, M. Neural response of cats to taste stimuli of varying temperatures. Jap. J. Physiol., 14:67-89, 1964.

8) Sato, M. And Yamashita, S. The effect of temperature on the taste response of rats. Published at 34 th General Meeting of Jap. Zool. Soc. held at Fukuoka in 1963.

9) Yamashita. S. Chemoreceptor response in frog, as modified by temperature change. Jap. J. Physiol., $14:$ 488-504. 